\title{
A NOVEL APPROACH FOR THE IMPROVEMENT OF OPEN CIRCUIT VOLTAGE AND FILL FACTOR OF InGaAsSb/GaSb TPV CELLS
}

G. Charache, D. Z. Garbuzov, et. al.

October 1997

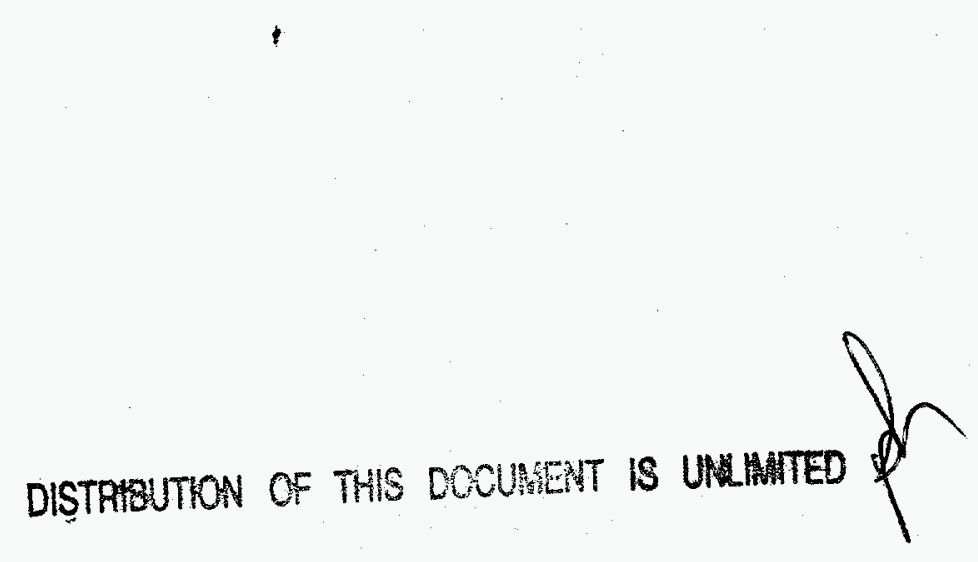

NOTICE

MASTER

This report was prepared as an account of work sponsored by the United States Government. Neither the United States, nor the United States Department of Energy, nor any of their employees, nor any of their contractors, subcontractors, or their employees, makes any warranty, express or implied, or assumes any legal liability or responsibility for the accuracy, completeness or usefulness of any information, apparatus, product or process disclosed, or represents that its use would not infringe privately owned rights.

Operated for the U. S. Department of Energy

by KAPL, Inc. a Lockheed Martin company 


\section{DISCLAIMER}

This report was prepared as an account of work sponsored by an agency of the United States Goverament. Neither the United States Government nor any agency thereof, nor any of their employees, makes any wartanty, expross or implied, or assumes any legal liability or responsibility for the accuracy, completeress, or usefulness of any information, apparatus, product, or process disclosed, or represents that its use would not infringe privately owned rights. Reference berein to any specific commercial product, process, or service by trade name, tradernark inanufacturer, or otherwise does not necessarily constitute or imply its endorsement. recommendation, or favoring by the United States Goverameat or any ageacy thereof. The views and opinions of authors expressed herein do not necessarily state or reflect those of the United States Government or any agency thereof. 


\section{DISCLAIMER}

Portions of this document may be illegible in electronic image products. Images are produced from the best available original document. 


\title{
A NOVEL APPROACH FOR THE IMPROVEMENT OF OPEN CIRCUIT VOLTAGE AND FILL FACTOR OF InGaAsSb/GaSb THERMOPHOTOVOLTAIC CELLS
}

\author{
Dmitri Z. Garbuzov, Ramon U. Martinelli, \\ Victor Khalfin, Hao Lee, Nancy A. Morris, \\ Gordon C. Taylor and John C. Connolly \\ Sarnoff Corporation 201 Washington Rd. \\ Princeton, NJ 08543-5300 \\ (609) 734-2000
}

\author{
Greg W. Charache, David M. \\ DePoy \\ Lockheed-Martin, Inc. \\ Schenectady, NY 12301-1072
}

\begin{abstract}
Heterojunction $\mathrm{n}-\mathrm{Al}_{0.25} \mathrm{Ga}_{0.75} \mathrm{As} \mathrm{s}_{0.02} \mathrm{Sb}_{0.98} / \mathrm{p}-\mathrm{In}_{0.16} \mathrm{Ga}_{0.84} \mathrm{As}_{0.04} \mathrm{Sb}_{0.96}$ thermophotovoltaic (TPV) cells were grown by molecular-beam epitaxy on $n$-GaSb-substrates. In the spectral range from $1 \mu \mathrm{m}$ to $2.1 \mu \mathrm{m}$ these cells, as well as homojunction $\mathrm{n}$ - $\mathrm{p}-\mathrm{In}_{0.16} \mathrm{Ga}_{0.84} \mathrm{As}_{0.04} \mathrm{Sb}_{0.96}$ cells, have demonstrated internal quantum efficiencies exceeding $80 \%$, despite about a $200 \mathrm{meV}$ barrier in the conduction band at the heterointerface. Estimation shows that the thermal emission of the electrons photogenerated in p-region over this barrier can provide high efficiency for hetero-cells if the electron recombination time in $\mathrm{p}-\mathrm{In}_{0.16} \mathrm{Ga}_{0.84} \mathrm{As}_{0.04} \mathrm{Sb}_{0.96}$ is longer than 10 ns. Keeping the same internal efficiency as homojunction cells, hetero-cells provide a unique opportunity to decrease the dark forward current and thereby increase open circuit voltage $\left(V_{o}\right)$ and fill factor at a given illumination level. It is shown that the decrease of the forward current in hetero-cells is due to the lower recombination rate in n-type wider-bandgap space-charge region and to the suppression of the hole component of the forward current. The improvement in $\mathrm{V}_{\alpha}$ reaches $100 \%$ at illumination level equivalent to $1 \mathrm{~mA} / \mathrm{cm}^{2}$ and it decreases to $5 \%$ at the highest illumination levels $\left(2-3 \mathrm{~A} / \mathrm{cm}^{2}\right)$, where the electron current component dominates in both the homo- and heterojunction cells. Values of $\mathrm{V}_{\infty}$ as high as 310 $\mathrm{meV}$ have been obtained for a hetero-cell at illumination levels of $3 \mathrm{~A} / \mathrm{cm}^{2}$. Under this condition, the expected fill factor value is about $72 \%$ for a hetero-cell with improved series resistance. The heterojunction concept provides excellent prospects for further reduction of the dark forward current in TPV cells.
\end{abstract}

\section{INTRODUCTION}

Thermophotovoltaic (TPV) cells intended for direct conversion of blackbody radiation to electrical energy should be based on the narrow band gap $\left(E_{g}\right)$ materials which provide effective absorption of the blackbody infrared radiation. For example, given a blackbody at a temperature of $1000^{\circ} \mathrm{C}$, materials with $E_{\mathrm{g}} \leq 0.55 \mathrm{eV}$ are desirable (Wojtczuk 1994). $\quad \mathrm{In}_{\mathrm{x}} \mathrm{Ga}_{1-\mathrm{x}} \mathrm{As}$ compounds with $\mathrm{x}=0.7-0.75$ grown on $\operatorname{InP}$ substrates were the first materials successfully used for TPV application. However, the fact that $\mathrm{In}_{0.7} \mathrm{Ga}_{0,3}$ As layers are lattice mismatched with InP substrate can limit the device performance. Recently, $\mathrm{In}_{0.16} \mathrm{Ga}_{0.94} \mathrm{As}_{0.04} \mathrm{Sb}_{0.96}$ layers lattice matched to GaSb substrate were utilized for TPV cell fabrication and the results comparable to the best achievements for InGaAs/InP devices have been obtained. (Wang 1997, Martinelli 1997 and Charache 1997). Both types of TPV cells display internal quantum efficiencies $\left(\eta_{i}\right)$ higher than $80 \%$ for radiation from $1 \mu \mathrm{m}$ to $2.1 \mu \mathrm{m}$; hence, the potential for improvement in $\eta_{i}$ for these materials is very small. On the other hand, the open circuit voltage for TPV cells designed for $1000{ }^{\circ} \mathrm{C}$ blackbody radiation is only about $55 \%$ of the $0.55 \mathrm{eV}$ material band gap (Charache 1997), and a search for $V_{a x}$ improvement is very reasonable.

The opportunities of increasing $\mathrm{V}_{a}$ using a heterojunction cell design is considered in this paper. High quality heterojunctions in the AlGaAsSb/InGaAsSb system lattice matched with GaSb are well developed 
for the laser diode applications, while the possibility of growing a heterojunction between $\operatorname{In}_{n}, G a_{0}$ As and a wider bandgap compound is questionable. This fact enhances the advantages of Gasb laituce-matched materials for TPV application compared with those of InGaAs/InP system.

\section{STRUCTURES, DEVICE FABRICATIONAND MEASURMENTS}

The TPV cells under consideration were prepared from thiee structures grown by solid-source, molecular-beam epitaxy. Two structures ( $A$ and $B$ ) were identical and comprise a homo-p-n-junction in

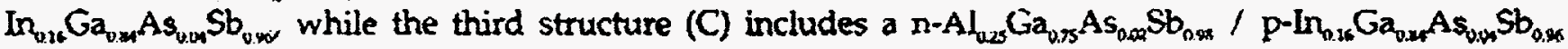
heterojunction. The heterojunction structure $C$ was different from structures $A$ and $B$ only in the composition of the $n$-region of $p-n$ junction. As seen from Fig. la, the layers comprising these structures were grown on $n-G a S b$ substrates in the following order: a 0.5 um-thick $n$-GaSb buffer layer; a 1 um-thick

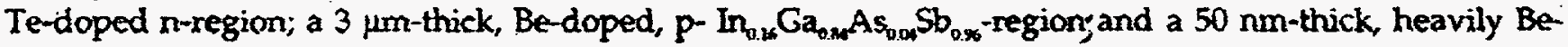
doped, GaSb-window layer. In the case of structures $A$ and $B$, the n-region has the same composition as the p-region, but was Te-doped to $n=3 \times 10^{37} \mathrm{~cm}^{-3}$. In the case of the heterojunction structure, the $n$ -

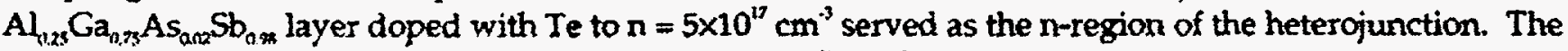
p-region in all the structures was doped to $p=1 \times 10^{13} \mathrm{~cm}^{-3}$, while the top GaSb window had a hole concentration of $2 \times 10^{34} \mathrm{~cm}^{3}$.

Small-area, mesa-configuration cells were prepared from structures $A$ and $C$ and large area, $4 \times 4 \mathrm{~mm}^{2}$ plane cells were fabricated from structures $B$ and $C$. The mesa-devices (Figure 1a) had a ring contact on the p-side around the $\$ 00 \mu \mathrm{m}$-diameter illuminated area. The configuration of the finger-stripe contact on the surface of the planar devices is shown in Figure $\mathrm{lb}$. Ti-Pt-Au/Ti-Au and $\mathrm{Cr}$-Au multi-layer compositions were used for p-contact preparation in the planar-and mesa-devices, respectively. In the case of the planar cells, 5- $\mu \mathrm{m}$-thick layers of Au were plated on the top of the stripe-contacts to reduce device resistance. For both types of devices, after p-contact deposition the wafers were thinned to $150 \mu \mathrm{m}$ and then $\mathrm{Au} / \mathrm{Ge} / \mathrm{Ni} / \mathrm{Au}$ (planar devices) or $\mathrm{Sn}-\mathrm{Au}$ (mesa cells) ohmic contacts were prepared on the substrate side.

The TPV cells of both types were mounted with In solder into the copper heatsinks and bolked to a water-cooled, temperature-controlled block. A high-power $1.5 \mu \mathrm{m}$ diode laser was used as the radiation source for the mesa-device testing. An incandescent microscope illuninator was used to obtain uniform illumination for the large area planar cells. A lens focused illuminator light provided photocurrent densities comparable to or higher than those obtained from the $1000^{\circ} \mathrm{C}$ blackbody radiation source. For both types of cells the short circuit current density $\left(J_{n}\right)$ and open circuit voltage were measured as a function of illumination. Some precautions were undertaken during $f_{\text {ss }}$ measurements for large area devices to maintain short-circuit conditions under high illumination levels. The photocells were connected to a load by $1 \mathrm{~mm}$ diameter, $5-\mathrm{cm}$-long wires soldered to the cells. The resistance of the circuit without any load resistance was less than $0.002 \Omega$ A $0.1 \Omega$ load resistance was used for the $J_{\kappa}$ measurements. Besides $J_{*}$ versus $v_{o c}$ characteristics, the absolute values of the extemal quantum efficiency $\left(\eta_{v}\right)$ and the spectral dependence of $\eta_{k}$ were measured, using technique described earliex (Martinelli 1997).

\section{QUANTUM EFHICIENCY AND BAND DIAGRAM OF HETEROIUNCTION CELLS}

The spectral dependencies of $\eta_{\text {r }}$ for uncoated heterojunction mesa-cell (structure $C$, solid line) and homojunction cell (structure $A$, dashed line) are shown in Figure 2. For both devices $\eta_{\mathrm{e}}$ exceeds $50 \%$ in the broad spectral range from $1 \mu$ to $2.1 \mu \mathrm{m}$. Taking into account that the reflectivity of uncoated cell surfaces varies from $42 \%$ to $39 \%$ in this spectral range, one can find that for both devices more than $80 \%$ 


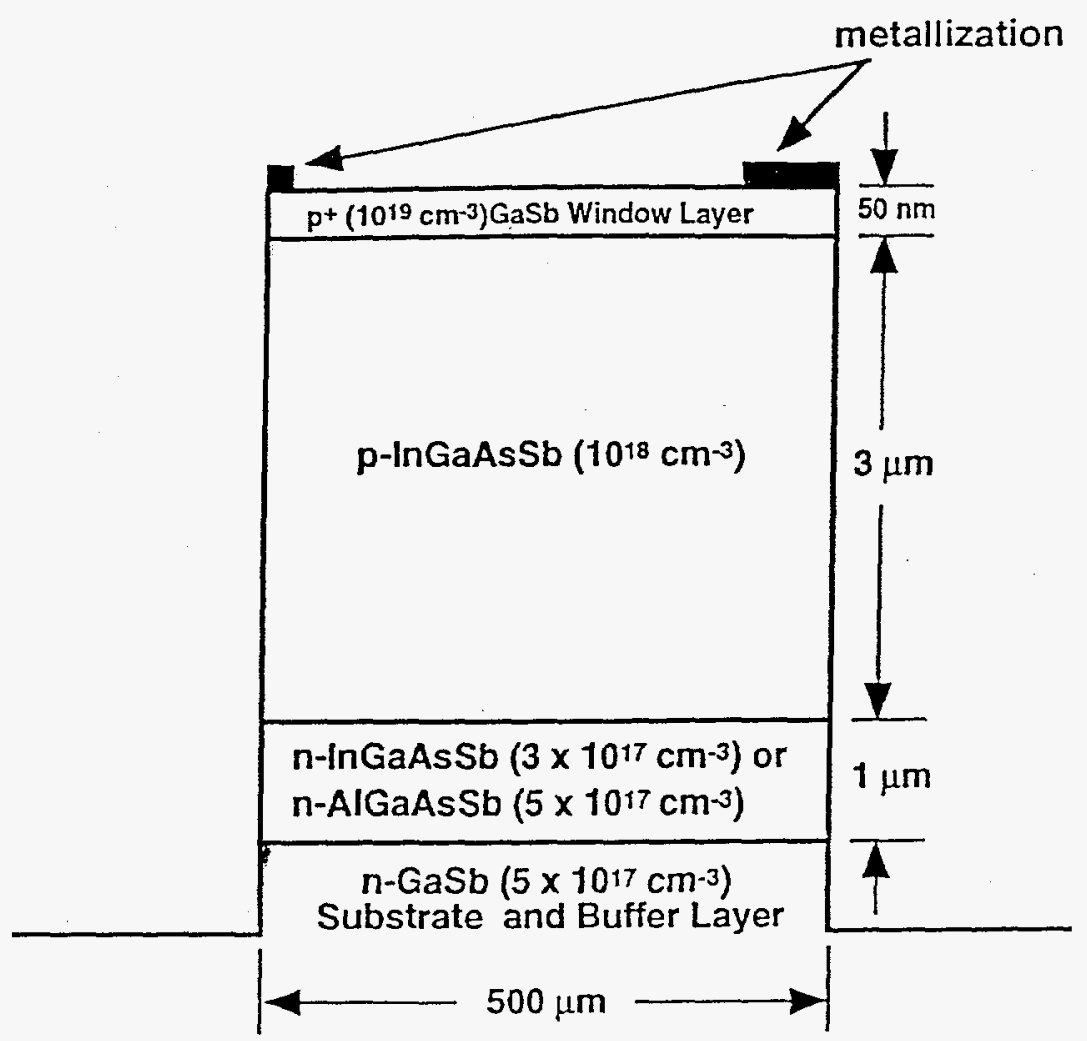

(a)

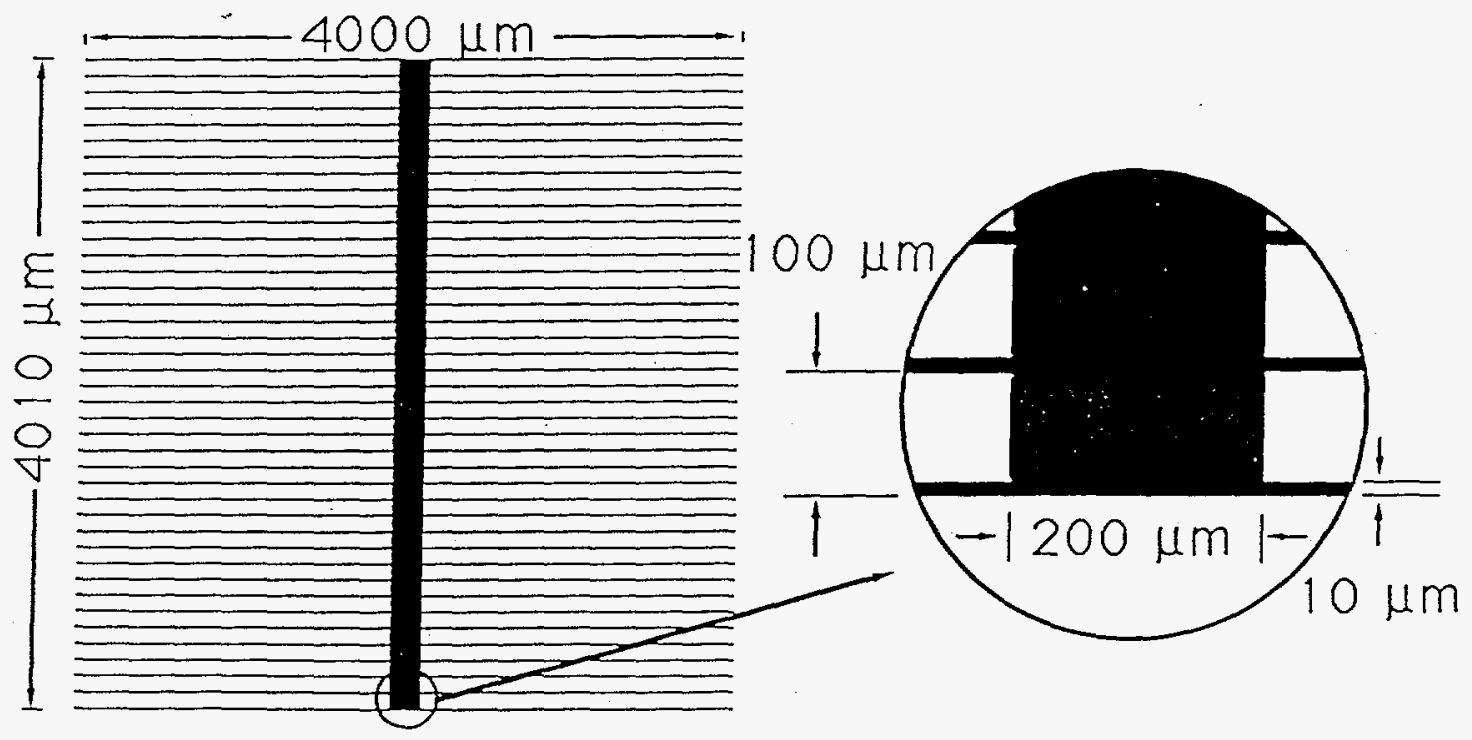

(b)

FIGURE 1. (a) Cross Section of Mesa-Cell, (b) p-side-Contact Configuration for Planar Cell. 
of the photogenerated carriers contribute to the photocurrent. Two conclusions follow from this result: (1) the diffusion length for the excess electrons in $\mathrm{p}-\mathrm{In}_{0.16} \mathrm{Ga}_{0.94} \mathrm{As}_{\mathrm{n}, 1.44} \mathrm{Sb}_{0.96}$ layers is considerably longer than $\mathrm{p}$ layer thickness (Martinelli 1997), and (2), the heterojunction barrier does not increase the recombination losses in the p-region.

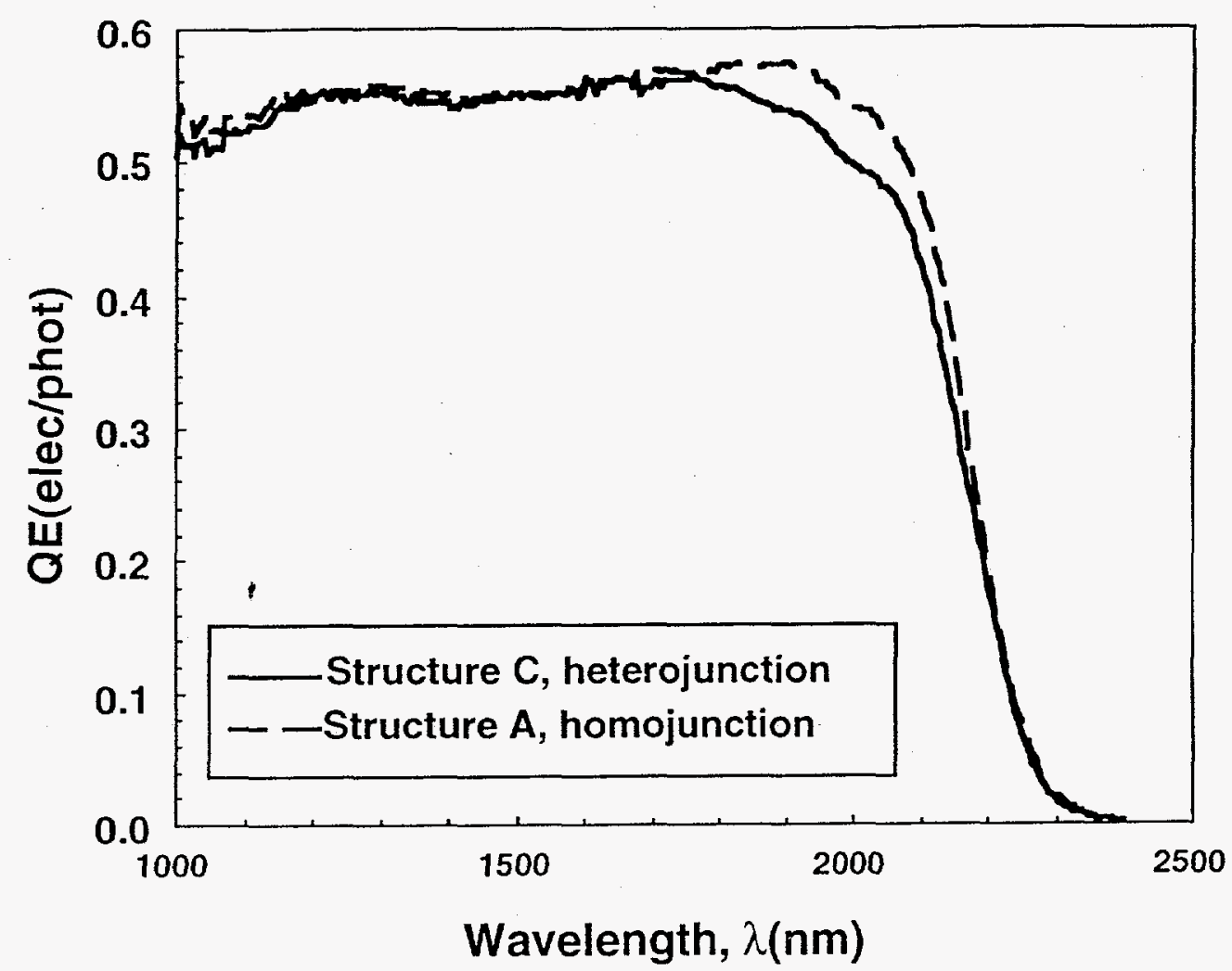

FIGURE 2. Spectral Dependence of External Quantum Efficiency for Uncoated Hetero- and Homojunction Mesa-Cells.

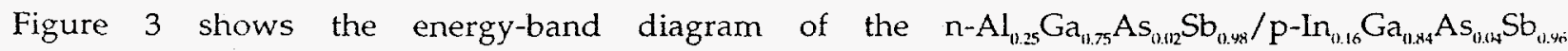
heterojunction cell under an illumination level corresponding to $\mathrm{V}_{\mathrm{u}}=300 \mathrm{mV}$. Tsou's band parameters were used for the energy-band diagram (Tsou 1992). The hetero-barrier of $220 \mathrm{meV}$ height in the conduction band might block the flow of the excess electrons generated in p-region. The value of the additional recombination loss caused by this barrier depends on the ratio of the rate of the electron thermal emission over the barrier to the recombination rate in the p-region. Estimations show that greater than $80 \%$ electron thermal injection efficiency over this barrier can be reached if the electron lifetime in $p$ region, $\tau_{\mathrm{e}^{\prime}}$ is longer than $10 \mathrm{~ns}$. Taking a value of $1600 \mathrm{~cm}^{2} / \mathrm{V} s$ for electron mobility, $\mu_{\mathrm{e}}$, in $\mathrm{p}$-InGaAsSb, one can obtain a value of $6 \mu \mathrm{m}$ for electron diffusion length, $L_{e^{\prime}}$ in p-region $\left(L_{t}=\sqrt{\tau_{e} \cdot D_{e}}\right)$. This value is in agreement with estimation from the data on the shape of the spectral response (Martinelli 1997). 


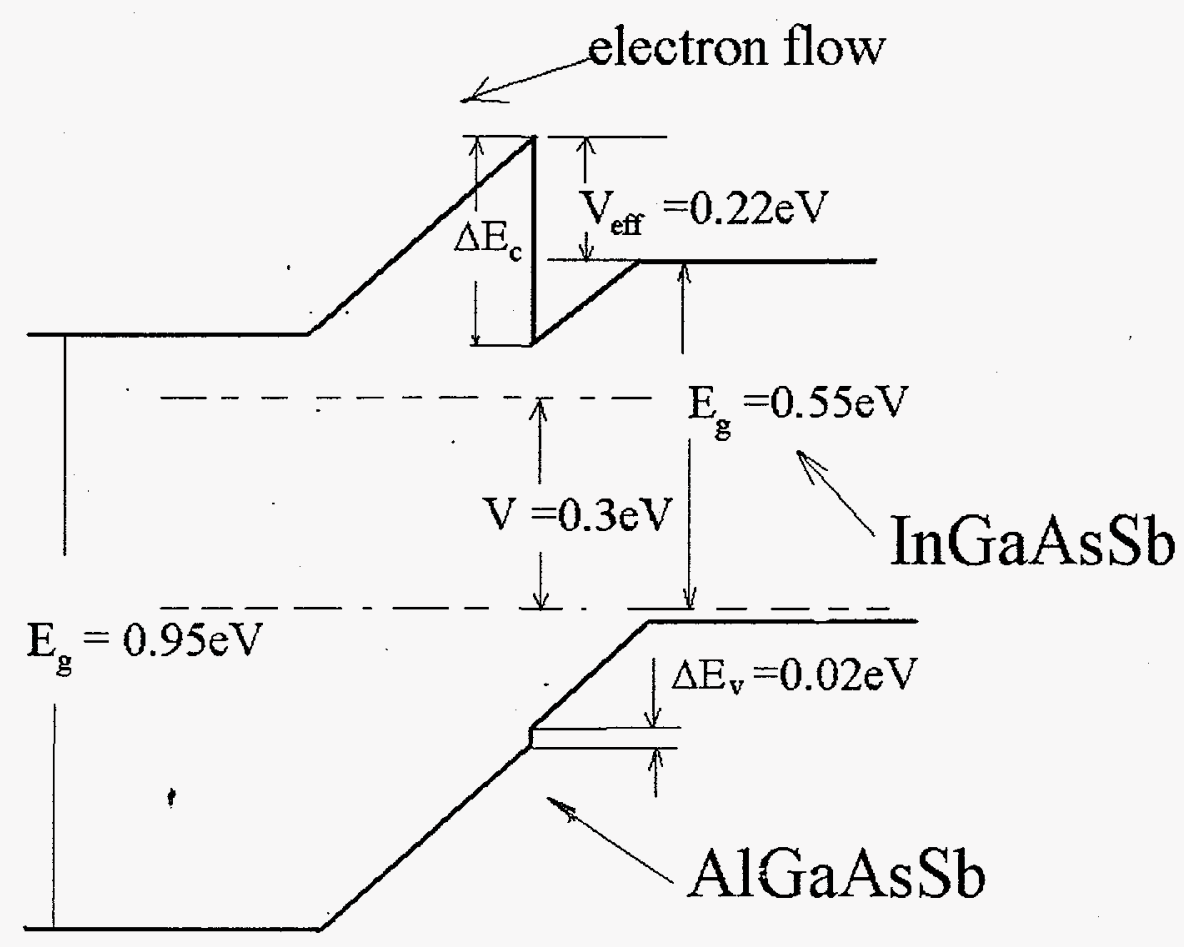

FIGURE 3. Energy-Band Diagram of a Heterojunction Cell.

\section{CURRENT-VOLTAGE AND $\mathrm{I}_{\underline{S C}}$ VERSUS $\mathrm{V}_{\underline{Q S}}$ CHARACTERISTICS}

The dark forẅard I-V characteristics for homo- and heterojunction mesa-cells are shown in Figure 4. The excess current in homojunction is caused by the recombination in the space-charge region and by the hole injection into the n-region of the $\mathrm{p}-\mathrm{n}$ junction. In the case of the heterojunction with a heavily doped $\mathrm{p}$ InGaAsSb region, the main part of the space-charge region is located in the wider band gap AlGaAsSb material. Assuming that the deep level concentration in $\mathrm{n}-\mathrm{Al}_{0.25} \mathrm{Ga}_{0.75} \mathrm{As}_{0.02} \mathrm{Sb}_{0.98}$ does not exceed significantly that in the $\mathrm{n}-\mathrm{In}_{0.16} \mathrm{Ga}_{0.84} \mathrm{As}_{0.04} \mathrm{Sb}_{0.96}$, the rate of recombination via deep levels in the space charge region will be decreased by the factor $\exp \left(-\Delta \mathrm{E}_{\mathrm{g}} / 2 \mathrm{kT}\right)$. Where $\Delta \mathrm{E}_{\mathrm{g}}=400 \mathrm{mV}$ is the difference between the bandgaps of $\mathrm{Al}_{0.25} \mathrm{Ga}_{0.75} \mathrm{As}_{\mathrm{v}, 02.2} \mathrm{Sb}_{0.98}$ and $\mathrm{In}_{0.16} \mathrm{Ga}_{0.84} \mathrm{As}_{0.04} \mathrm{Sb}_{0.96}$. The offset barrier in the valence band of the heterojunction should also lead to reduction of the hole injection current.

Due to the reduction of these two current components, the I-V characteristics of heterojunction cells, at the 200 to $300 \mathrm{mV}$ voltage range, can be approximated by the exponent with ideality factor of $n=1.1$. Thus the corresponding current component is the result of the electron injection into $\mathrm{p}-\mathrm{In}_{0.16} \mathrm{Ga}_{0.84} \mathrm{As}_{0.04} \mathrm{Sb}_{0.96}$. The electron current components in hetero- and homojunction TPV cells should be equal at a given voltage (V), and solid and dashed curves converge at $\mathrm{V}>350 \mathrm{meV}$, confirming this fact. This convergence also shows that the series resistances are the same for hetero- and homojunction devices.

It is clear that there is a direct correspondence between the dark forward I-V characteristic and the $V_{o}$ value at a given illumination level. The open circuit voltage at a given illumination level can be found from the relation: 


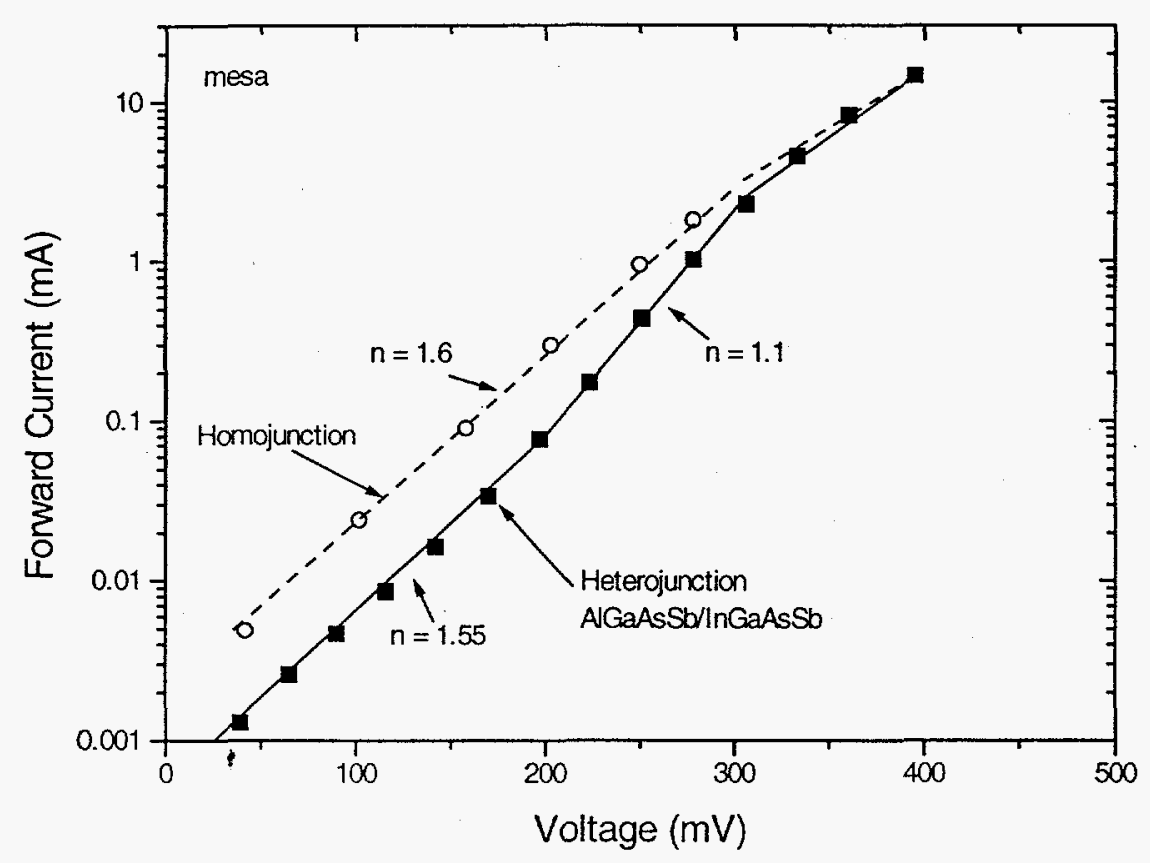

FIGURE 4. Dark Forward I-V Characteristics of the Homojunction (Structure A) and Heterojunction (Structure C) Mesa-Cells.

$$
\eta_{e} \cdot P=S \cdot J(V)_{V=V_{o c}} / q
$$

where: $P$ (photon/s) is the photon flux incident on the device active area (S), $\eta_{e}$ is a TPV cell external quantum efficiency, and $J(V)=J_{0} e^{(q V / n k T)}$ is the diode dark forward current density at $V=V_{a c}$. It follows from equation (1) that a decrease of the forward current at a given voltage increases the photovoltage at a given illumination.

Figure 5 demonstrates the dependencies of the short current densities on the open circuit voltage, measured for the compared mesa-devices using a high-power $1.5 \mu \mathrm{m}$ laser as the radiation source. In accordance with difference in dark I-V-characteristics shown in Fig. 4, the $\mathrm{V}_{c \mathrm{cc}}$ values are higher for the heterojunction cell throughout the range of the illumination levels used. The $\mathrm{V}_{\text {ox }}$ difference is $70 \mathrm{meV}$ at the lowest excitation level, $30 \mathrm{meV}$ at $J_{\mathrm{sc}}=0.1 \mathrm{~A} / \mathrm{cm}^{2}$, and about $12 \mathrm{meV}$ at $J_{\mathrm{sc}}=2 \mathrm{~A} / \mathrm{cm}^{2}$. At the maximum laser power, the measured values of $J_{x c}$ and $V_{c x}$ were $30 \mathrm{~A} / \mathrm{cm}^{2}$ and $375 \mathrm{meV}$ for the heterojunction cell, and these values were lower ( $27 \mathrm{~A} / \mathrm{cm}^{2}$ and $360 \mathrm{mV}$ ) for the homojunction cell.

The fraction of the $J_{x}$ versus $V_{c}$ dependence corresponding to the electron injection current (Figure 5) is significantly more pronounced than in the case of I-V characteristics (Figure 4), because of the absence of the series resistance "masking" effect. The value of $\mathrm{J}_{0}$ found for the electron current component (Figure 5) is about $30 \pm 10 \mu \mathrm{A} / \mathrm{cm}^{2}$. 


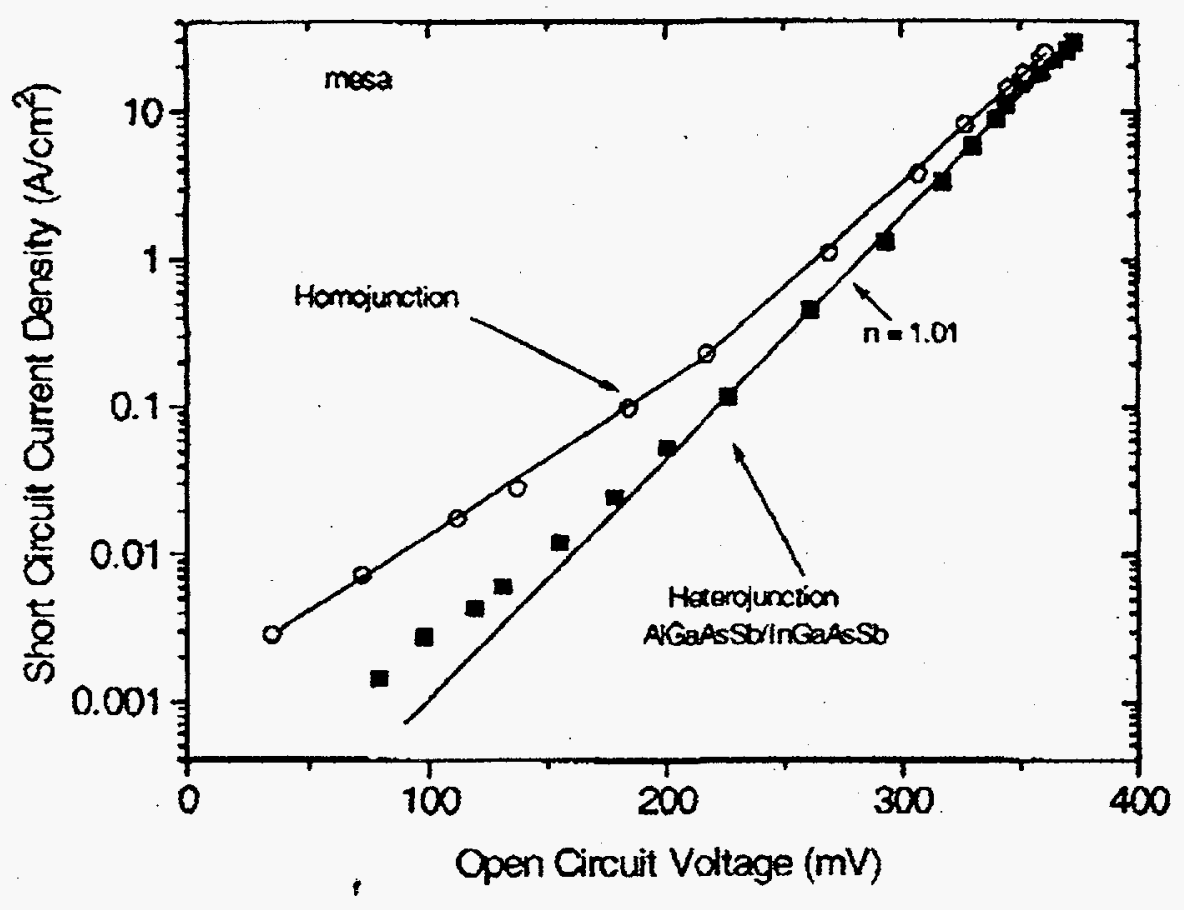

FIGURE 5. $I_{x}$ versus $V_{s c}$ Dependencies for Homojunction (Structure $A$ ) and Heterojunction (Structure C) Mesa-Cells.

The dependencies of $\mathrm{J}_{\text {se }}$ versus $\mathrm{V}_{o}$ for planar, $4 \times 4 \mathrm{~mm}^{2}$ hetero- and homojunction (structure $B$ ) cells are shown in Figure 6. The comparison of these dependencies demonstrates the same features as seen in Figure 5 and confirms that the difference between homo- and heterojunction devices is not related to structure or device fabrication peculiarities. The $I_{\infty x}-V_{\alpha c}$ characteristic for the heterojunction cell in Figure 6 can be well fitted exponentially with an ideality factor of $1.05 \pm 0.04$. The $4 \%$ variation of the ideality factor leads to the variation of $y_{s}$ in the range from 25 to $50 \mu \mathrm{A} / \mathrm{cm}^{2}$.

\section{SERLES RESISTANCE AND FULLEACTOR}

There are reasons to assume that in the planar cells the area-distributions of the forward current and photocurrent are similar and uniform over the device area. The solid circles in Figure 6 represent dark forward I-V characteristic of the heterojunction cell. The voltage difference in $I-V$ and $I_{\alpha}-V_{\text {.* }}$ characteristics can be attributed to the effect of the series resistance on I-V characteristic. The values of the device specific resistance $\left(\Omega \mathrm{cm}^{2}\right)$ calculated from these differences are shown in Figure 7 . As shown, the series specific resistance strongly depends on the current density in the range of the current density less than $700 \mathrm{~mA} / \mathrm{cm}^{2}$, and it is approximately constant $\left(0.02 \Omega \mathrm{cm}^{2}\right)$ at higher current densities.

The obtained values of $R_{s}$ were used to calculate the fill factor (FF) for the hetero-cell under discussion. The FF experimental data are shown by the large solid circles in Figure 8. To obtain these data-points, the measurements of the photovoltage and photocurrent as a function of the load resistance were performed at five levels of illumination. The optimum load for the point measured at the lowest illumination level was $13.2 \Omega$, and $0.67 \Omega$ at the highest illumination levels. 


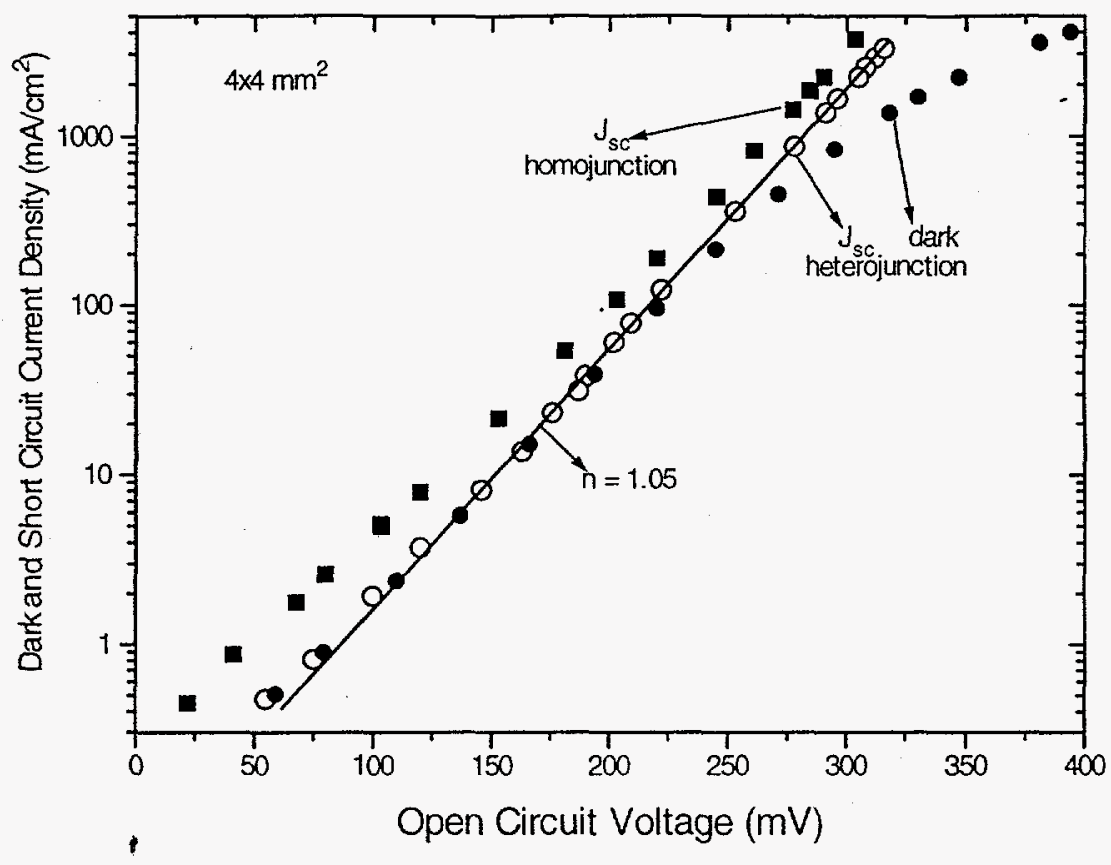

FIGURE 6. Solid Squares and Open Circles Present $J_{x}-V_{w}$ Characteristics for Planar Homojunction Cell (Structure B) and Heterojunction Cell (Structure C). Dark I-V Characteristic for Planar Hetero-Cell is Shown by Solid Circles.

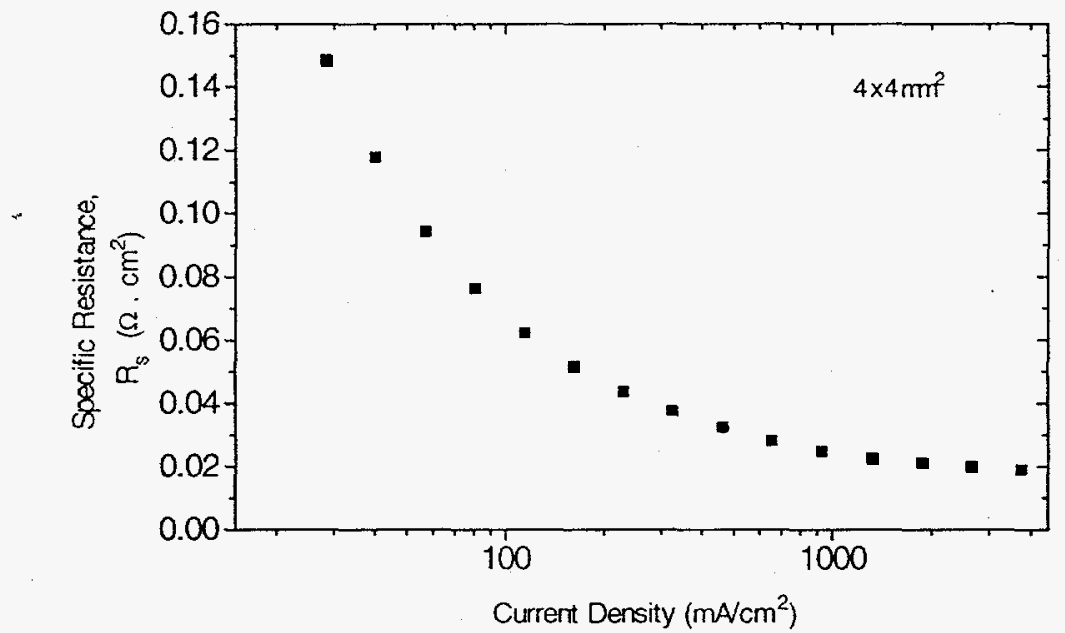

FIGURE 7. Dependence of Series Specific Resistance on Current for Planar Heterojunction Cell Determined from the Comparison of $J_{s c}-V_{c c}$ and the Forward Dark I-V Characteristics Shown in Figure 6. 


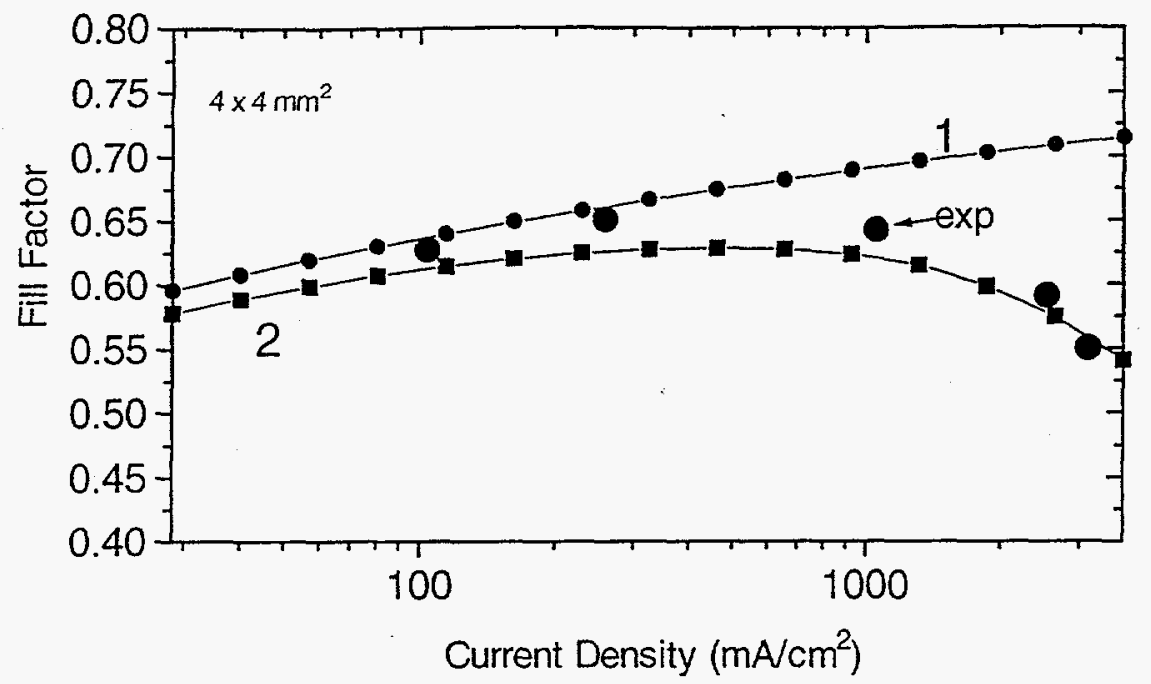

FIGURE 8. Curves 1 and 2 are the Fill Factor Calculated for a Planar Hetero-Cell with $R_{s}=0$ and with Data on $R_{s}$ Taken from Figure 7. The large Solid Circles Represent Experimental Fill-Factor Data for a Planar Hetero-Cell.

The fill factor for the considered hetero-cell was calculated under two different assumptions: (1) curve 1 in Figure 8 gives "ideal" FF calculated neglecting series resistance and (2) curve 2 was calculated using values of the series specific resistance shown in Figure 7. Unexpectedly, the FF experimental values at low and moderate illumination levels were higher than those calculated with the experimental values of series resistance. This means that series resistance for photocurrent is less than the series resistance for the dark current in the range of current densities $100<\mathrm{J}<1000 \mathrm{~mA} / \mathrm{cm}^{2}$. The difference in the area distribution for the dark current and photocurrent, or the incorporation of an additional rectifying junction could be the reasons for this phenomena. At the excitation level of practical interest $(U \geq 1000$ $\mathrm{mA} / \mathrm{cm}^{2}$ ) measured values of $\mathrm{FF}$ are in reasonable agreement with those calculated for cell specific resistance $R_{S}=0.02 \Omega \mathrm{cm}^{2}$ that weakly depend on current in this region of current densities. At the highest illumination levels the influence of non-ohmic resistance components on FF become insignificant in comparison to the ohmic series resistance. However, the corresponding value of specific resistance $R_{s}$ $=0.02 \Omega \mathrm{cm}^{2}$ is too high in comparison with expected bulk device specific resistance, and it leads to the decrease of FF for studied photocells from an "ideal" value of 0.72 to an observed value of 0.55 at the highest illumination level. Some improvements in TPV cell fabrication should decrease $R_{s}$ to the level at which FF values close to the ideal will be achieved. The estimation for this "ideal" case shows that for radiation with photon energy equal to the p-region bandgap a power conversion efficiency as high as $42 \%$ could be achieved for heterojunction cells at photocurrent density of $3 \mathrm{~A} / \mathrm{cm}^{2}$, and possibly can be even higher at higher illumination levels.

\section{CONCLUSION}

In conclusion, heterojunction $\mathrm{n}-\mathrm{Al}_{0,25} \mathrm{Ga}_{0.75} \mathrm{As}_{0,02} \mathrm{Sb}_{0.98} / \mathrm{p}-\mathrm{In}_{0.16} \mathrm{Ga}_{0.84} \mathrm{As}_{0,1 \mathrm{H}} \mathrm{Sb}_{1 \mathrm{i}, 46}$ TPV cells lattice-matched with $\mathrm{GaSb}$ have been demonstrated. Their internal efficiency in the spectral range from $1 \mu \mathrm{m}$ to $2.1 \mu \mathrm{m}$, as well

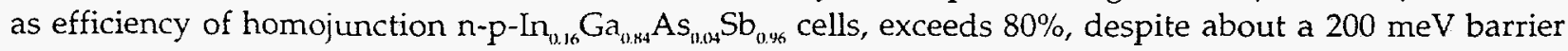
in the conduction band at the heterointerface. The forward dark current at a given voltage is less in the heterojunction cells than that in homojunction devices because the space charge recombination rate and 
current hole component of this current are considerably suppressed. This leads to a $100 \%$ increase of the open circuit voltage in the heterojunction cell at low illumination levels. The improvement in $V_{\alpha}$ decreases to $5 \%$ at the illumination levels of practical interest $\left(2-3 \mathrm{~A} / \mathrm{cm}^{2}\right)$ because the electron component of the dark current dominates at this condition in both homo- and heterojunction devices. The reduction of the electron dark current component (which can be related to both intrinsic, bulk recombination and surface recombination in the p-region) seems to be a key factor for further improvement in the TPV cell performance. The corresponding improvement is expected to be more significant for the heterojunction cells, since other current components are already suppressed in this case.

\section{Acknowledgement}

The authors thank M. Harvey, D. Capewell, R. Farkas and R. Matarese for technical assistance.

\section{References}

Charache, G. W. et al. (1997) "Infrared Materials for Thermophotovoltaic Applications" presented at the Electronic Materials Research Conference, Ft. Collins, CO, June 25-27, 1997.

Martinelli, R. U. et al. (1997) "Minority Carrier Transport in InGaAsSb Thermophotovoltaic Cells, presented at Thermophotovoltaic Generation of Electricity: Third NREL Conference, Couts, T. J., Allman, C. S. and Benner, J. P., eds, AIP Conf. Proc 401, Colorado Springs, CO, 401:389-395.

Tsou ,Y., A. Ichii, and E. M. Garmire (1992) "Improving InAs Double Heterostructure Lasers with Better Confinement," IEEE J. Quantum Electronics" 28:1261-1266.

Wang, C. W., H. K. Choi, G. W. Turner, and M. J. Manfra, (1997) "Lattice-Matched Epitaxial GaInAsSb Thermophotovoltaic Devices" presented at Thermophotovoltaic Generation of Electricity: Third NREL Conference, Couts, T. J., Allman, C. S. and Benner, J. P., eds, AIP Conf. Proc 401, Colorado Springs, $\mathrm{CO}$.

Wojtczuk, S., E. Gagnon, L. Geoffroy, T. Parados, (1994) “InGaAs Thermophotovoltaic Cell Performance vs. Bandgap" presented at Thermophotovoltaic Generation of Electricity: First NREL Conference, Copper Mountain, CO, Couts, T. J., Allman, C. S. and Benner, J. P., eds AIP Conference Proceedings, 321:177-187. 